\title{
RADIOCARBON DATING OF TOTAL SOIL ORGANIC MATTER AND HUMIN FRACTION AND ITS COMPARISON WITH ${ }^{14} \mathrm{C}$ AGES OF FOSSIL CHARCOAL
}

\author{
L C R Pessenda ${ }^{1,2} \bullet$ S E M Gouveia ${ }^{1} \cdot$ R Aravena $^{3}$
}

\begin{abstract}
During the last decade radiocarbon dating has been used extensively in distinct regions of Brazil to provide information about soil chronology in paleoenvironmental studies. This paper presents ${ }^{14} \mathrm{C}$ data of soil organic matter (SOM), humin fraction, and charcoal in several soil profiles under natural vegetation from different Brazil locations (north, central, and southeast regions). The main objective is to compare the obtained ${ }^{14} \mathrm{C}$ dating of total SOM with humin, the oldest fraction of SOM. In order to validate the humin ages these data are compared with the age of charcoal collected at similar depths. The ${ }^{14} \mathrm{C}$ ages obtained on charcoal were, in most of the cases, in agreement with the humin fraction considering the experimental errors, or $20 \%$ older in average. The dates obtained from total SOM showed significantly younger ages than the humin fraction indicating contamination by younger carbon. These results show the humin fraction is considered a reliable material for ${ }^{14} \mathrm{C}$ dating in soils. However, the humin fraction ages could be assumed as the minimum ages for carbon in soils.
\end{abstract}

\section{INTRODUCTION}

The radiocarbon dating of the soil organic matter (SOM) is a polemic subject, mainly due to the complexity of the soil formation. Different studies have shown the SOM is formed by different components with different ages (Campbell et al. 1967; Scharpenseel et al. 1968; Martel and Paul 1974; Goh et al. 1976; Trumbore 1996). One of the problems for ${ }^{14} \mathrm{C}$ dating of SOM is contamination by invasion of roots, infiltration of organic compositions dissolved in water, influence of microorganisms, and of the soil fauna, resulting in the rejuvenating of the obtained ages (Nowaczyk and Pazdur 1990).

One alternative material is charcoal fragments found in the soils (Soubiès 1980; Saldarriaga and West 1986; Pessenda et al. 1996, 1998; Gouveia et al. 1999a, Gouveia and Pessenda 2000). These are considered biologically inert and physically stable in relation to isotopic changes with the environment, therefore, one of the more appropriate materials for the ${ }^{14} \mathrm{C}$ dating. Even if they absorb organic compounds from another soil layers, an acid-alkaline-acid treatment is enough to remove such contamination (European Science Foundation 1985). Therefore, it is possible to have a better understanding of ages profiles in soil by analyzing fractions of SOM horizons and comparing them with fossil charcoal, naturally buried at similar depths.

This paper focuses on the comparisons of the ${ }^{14} \mathrm{C}$ dating of SOM (total soil) and humin fraction, which is probably the more stable organic compound and, theoretically, the oldest and representative of the soil age (Balesdent 1987; Balesdent and Guillet 1992; Becker-Heidmann et al. 1988). The validity of the humin dating is verified by comparisons with the ${ }^{14} \mathrm{C}$ ages of charcoal collected in similar depths in different Brazilian regions (Pará, Minas Gerais, São Paulo, and Paraná States). This study is part of a major project aiming to use carbon isotopes to reconstruct paleovegetation changes during the Late Pleistocene and Holocene in Brazil (Pessenda et al. 1996a, 1996b, 1998, 2000).

\section{METHODS}

\section{Study Sites}

Samples for the comparison between the total SOM (total soil) and the humin fraction dating were collected in Londrina (Paraná State), Jaguariúna, Piracicaba, and Botucatu (São Paulo State), Alta-

\footnotetext{
${ }^{114}$ C Laboratory of Centre for Nuclear Energy in Agriculture, University of São Paulo, Piracicaba, SP, 13416-000, Brazil

${ }^{2}$ Corresponding author. Email: pessenda@ cena.usp.br.

${ }^{3}$ Department of Earth Sciences, University of Waterloo, Waterloo, Ontario, N2L 3G1, Canada
}

(C) 2001 by the Arizona Board of Regents on behalf of the University of Arizona Radiocarbon, Vol 43, Nr 2B, 2001, p 595-601

Proceedings of the 17 th International ${ }^{14} \mathrm{C}$ Conference, edited by I Carmi and E Boaretto 
mira (Pará State), and Humaitá (Amazonas State) (Figure 1). For the comparison between the humin and charcoal, the sampling sites were located in Salitre (Minas Gerais State), Jaguariúna, Anhembi, and Botucatu (São Paulo State). All soils were under natural vegetation (Table 1).

Table 1 Soil, vegetation types, and location of the study regions

\begin{tabular}{|c|c|c|c|}
\hline Site (state) & $\begin{array}{l}\text { Soil taxonomy } \\
\text { (USDA) }\end{array}$ & Vegetation & Location \\
\hline Londrina (PR) & Alfisol & $\begin{array}{l}\text { Mesophitic } \\
\text { Semideciduous forest }\end{array}$ & $23^{\circ} 19^{\prime} \mathrm{S} ; 51^{\circ} 22^{\prime} \mathrm{W}$ \\
\hline Botucatu (SP) & Oxisol & Semideciduous forest & $23^{\circ} \mathrm{S} ; 48^{\circ} \mathrm{W}$ \\
\hline Jaguariúna (SP) & Oxisol & Semideciduous forest & $22^{\circ} 40^{\prime} \mathrm{S} ; 47^{\circ} 1^{\prime} \mathrm{W}$ \\
\hline Anhembi (SP) & & Semideciduous forest & $22^{\circ} 45^{\prime} \mathrm{S} ; 47^{\circ} 58^{\prime} \mathrm{W}$ \\
\hline Piracicaba (SP) & Oxisol & Semideciduous forest & $22^{\circ} 41^{\prime} \mathrm{S} ; 47^{\circ} 40^{\prime} \mathrm{W}$ \\
\hline Salitre (MG) & Oxisol & $\begin{array}{l}\text { Mesophitic } \\
\text { Semideciduous forest }\end{array}$ & $19^{\circ} \mathrm{S}, 46^{\circ} 46^{\prime} \mathrm{W}$ \\
\hline Humaitá (AM) & Dystropept & $\begin{array}{l}\text { Savanna/tropical } \\
\text { forest }\end{array}$ & $7^{\circ} 31^{\prime} \mathrm{S}, 63^{\circ} 2^{\prime} \mathrm{W}$ \\
\hline Altamira (PA) & Alfisol & Tropical forest & $3^{\circ} 30^{\prime} \mathrm{S} ; 52^{\circ} 53^{\prime} \mathrm{W}$ \\
\hline
\end{tabular}

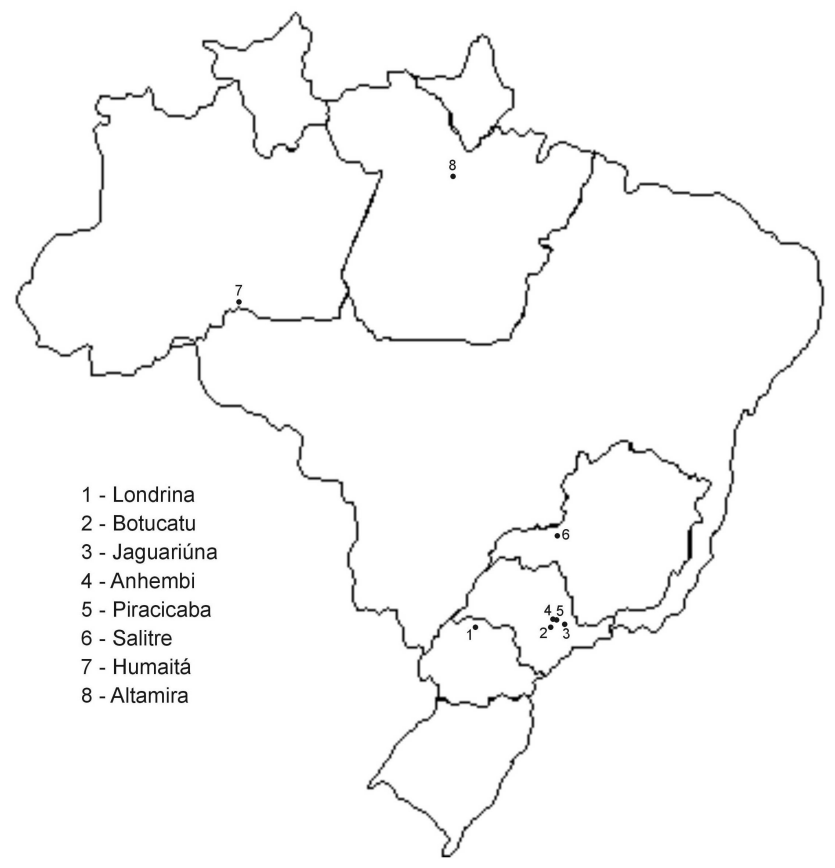

Figure 1 Map of Brazil showing the study sites 
In Humaitá and Botucatu sites the soils were collected from two trenches separated by approximately 2 $\mathrm{km}$ and $1.5 \mathrm{~km}$, respectively, denominated Humaitá I, Humaitá II, and Botucatu I, Botucatu II.

\section{Sampling and Analytical Aspects}

Soil samples were collected from excavations of $100 \mathrm{~cm} \times 200 \mathrm{~cm} \times 250 \mathrm{~cm}$ depth. Sampling involved the collection up to $10 \mathrm{~kg}$ of material at $10 \mathrm{~cm}$ intervals. Samples were dried at $60{ }^{\circ} \mathrm{C}$ to constant weight and sieved. Any remaining plant debris was removed by flotation in $\mathrm{HCl} 0.01 \mathrm{M}$. The total soil was then redried to constant weight and ${ }^{14} \mathrm{C}$ analyses were carried out at the Radiocarbon Laboratory of the Centre for Nuclear Energy in Agriculture (Brazil), using the benzene method and liquid scintillation counting (Pessenda and Camargo 1991).

The humin fraction was extracted from the total soil using acid-alkaline-acid treatment (Pessenda et al. 1996a). ${ }^{14} \mathrm{C}$ analyses were carried out at the Isotrace Laboratory of the University of Toronto (Canada) employing the AMS technique.

Charcoal was collected by hand-picking from soil samples and submitted to the conventional acidalkaline-acid treatment (Pessenda and Camargo 1991). ${ }^{14} \mathrm{C}$ analyses were carried out at the Radiocarbon Laboratory of the Centre for Nuclear Energy in Agriculture (Brazil) and the small samples were analyzed at the Isotrace Laboratory of the University of Toronto (Canada). The results are representative of the mean age of the charcoal fragments in the layers of $10 \mathrm{~cm}$ depth.

\section{RESULTS AND DISCUSSION}

\section{Total Soil and Humin Fraction}

The results of ${ }^{14} \mathrm{C}$ dating of the total soil and humin fraction of soils collected in six locations in different Brazilian areas are listed in Table 2 . The ${ }^{14} \mathrm{C}$ age profiles for the SOM and humin fraction show the expected trend of older ages with depth (Figure 2). One exception is the age inversion in the total soil at $140-150 \mathrm{~cm}$ depth in Altamira. In general, the SOM ages are significantly younger than the ${ }^{14} \mathrm{C}$ ages obtained on humin samples. This pattern has also been reported in other studies (Balesdent 1987; Balesdent and Guillet 1992; Becker-Heidmann et al. 1988). The Altamira soil showed the larger age difference among the soils analyzed in this study. Regarding individual profiles, the higher age differences are observed in the shallow layers reaching values up to $209 \%$ in the Londrina soil (Table 2). This can be related to the higher concentration of carbon content (specially fulvic and humic acids) present in the soil surface, compared with the deeper parts of the profile, that contributes significantly in the rejuvenating process of the total SOM. Some soils (Botucatu, Londrina, Altamira, and Humaitá) show a trend of decreasing ages difference with depth (Figure 2) suggesting the shallow layers are more affected by the input of younger carbon than the deeper layers. The influence of younger carbon could be also related to the type of vegetation. In Humaitá I, the humin in the 90-100 cm layer was 67\% older compared to the SOM. In Humaitá II, this difference was approximately $114 \%$. Considering the distance between these profiles $(2 \mathrm{~km})$, this pattern can be probably related to the fact that the decomposition of biomass is significantly higher under forest (trench II) than in the area of savanna-forest transition (trench I). Therefore, a higher input of recent organic matter by means of the biological activity and percolation was incorporated to the SOM, contaminating the profile and,consequently, turning it younger.

Summarizing, in all cases the humin ages were significantly older than the total soil samples in the same depths. Probably this is related to the presence of the fulvic and humic acids, compounds of the total soil that rejuvenates the SOM. During the chemical treatment, these acids are removed and consequently the residual humin fraction becomes older. 
Table $2{ }^{14} \mathrm{C}$ dating of the samples of total soil and humin in relation to soil depth. Values between brackets were estimated for interpolation and used for comparison effect.

\begin{tabular}{|c|c|c|c|c|}
\hline \multirow[b]{2}{*}{ Sites } & \multirow[b]{2}{*}{ Depth $(\mathrm{cm})$} & \multicolumn{2}{|c|}{${ }^{14} \mathrm{C}(\mathrm{BP})$} & \multirow{2}{*}{$\begin{array}{l}\text { Difference } \\
(\%)^{\mathrm{a}}\end{array}$} \\
\hline & & Total soil & Humin & \\
\hline \multirow[t]{3}{*}{ Londrina $^{\mathrm{b}}$} & $40-50$ & $820 \pm 60$ & $2530 \pm 70$ & 209 \\
\hline & $90-100$ & $2390 \pm 60$ & $3090 \pm 70$ & 29 \\
\hline & $170-180$ & $9340 \pm 120$ & $10,800 \pm 110$ & 16 \\
\hline \multirow{3}{*}{ Jaguariúna ${ }^{c}$} & $80-90$ & $3760 \pm 80$ & $4430 \pm 90$ & 18 \\
\hline & $150-160$ & $4720 \pm 80$ & $5820 \pm 70$ & 23 \\
\hline & $200-210$ & $5970 \pm 80$ & $7490 \pm 350$ & 25 \\
\hline \multirow[t]{3}{*}{ Piracicaba ${ }^{b}$} & $70-80$ & $2680 \pm 70$ & $3440 \pm 120$ & 28 \\
\hline & $90-100$ & $3030 \pm 70$ & $4260 \pm 110$ & 41 \\
\hline & $110-120$ & $3260 \pm 70$ & $4400 \pm 120$ & 35 \\
\hline \multirow[t]{3}{*}{ Botucatu Ic } & $60-70$ & $2690 \pm 60$ & $3930 \pm 80$ & 46 \\
\hline & $120-130$ & $4500 \pm 70$ & $5110 \pm 60$ & 14 \\
\hline & $180-190$ & $5750 \pm 70$ & $6490 \pm 120$ & 13 \\
\hline \multirow[t]{8}{*}{ Altamira ${ }^{b}$} & $40-50$ & $1440 \pm 70$ & (3970) & 176 \\
\hline & $50-60$ & (1870) & $4570 \pm 80$ & 144 \\
\hline & $70-80$ & $2790 \pm 80$ & $(5950)$ & 113 \\
\hline & $90-100$ & $3640 \pm 90$ & (7270) & 100 \\
\hline & $100-110$ & $(4230)$ & $8100 \pm 110$ & 91 \\
\hline & $110-120$ & $4800 \pm 80$ & $(8590)$ & 79 \\
\hline & $130-140$ & $(5650)$ & $9810 \pm 140$ & 74 \\
\hline & $140-150$ & $4390 \pm 90$ & - & - \\
\hline Humaitá I ${ }^{\mathrm{d}}$ & $90-100$ & $3570 \pm 130$ & $5960 \pm 260$ & 67 \\
\hline \multirow[t]{2}{*}{ Humaitá II ${ }^{\mathrm{d}}$} & $90-100$ & $2360 \pm 60$ & $5040 \pm 530$ & 114 \\
\hline & $180-190$ & $6130 \pm 90$ & $8170 \pm 430$ & 33 \\
\hline
\end{tabular}

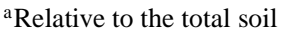

${ }^{b}$ Pessenda et al. 1996b

${ }^{\mathrm{c}}$ Gouveia et al. 1999b

${ }^{\mathrm{d}}$ Pessenda et al. 1998

${ }^{14} \mathrm{C}$ yr BP (ka)
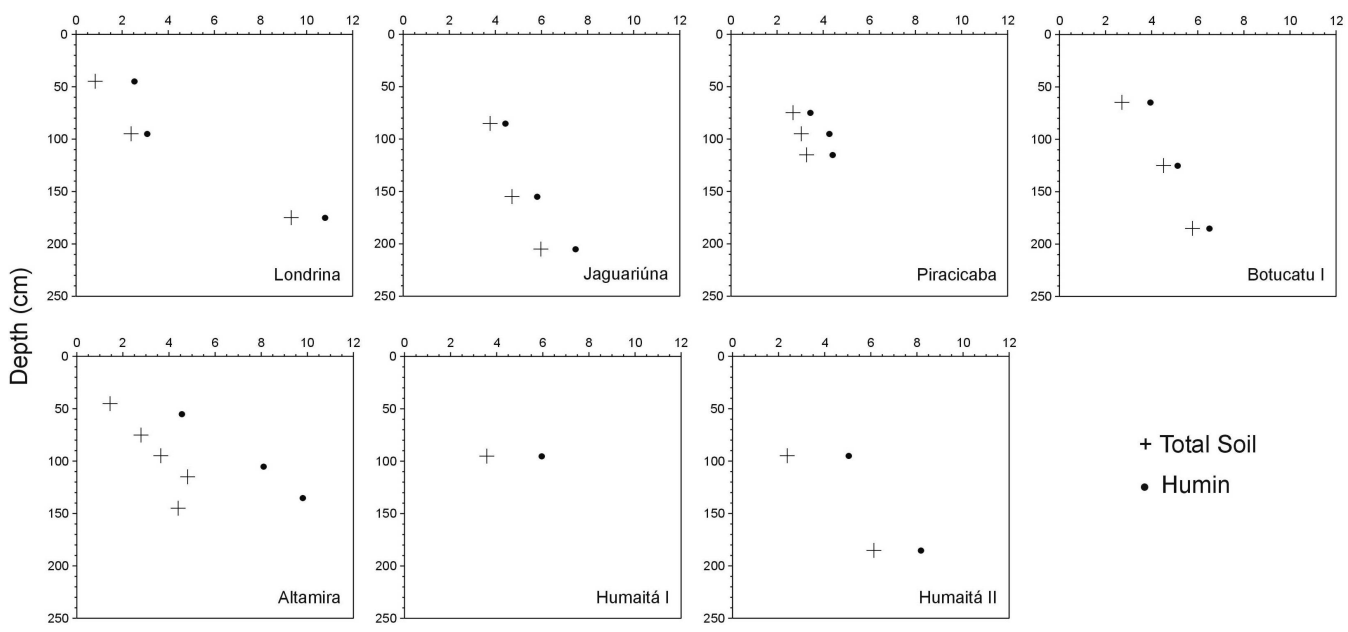

Figure 2 Comparison between total soil and humin ages 


\section{Humin Fraction and Charcoal}

In order to evaluate and constrain the humin ages, these results were compared with ${ }^{14} \mathrm{C}$ ages obtained in charcoal fragments collected at the same depths. This comparison is presented in the Table 3 and Figure 3.

Table $3{ }^{14} \mathrm{C}$ ages of the humin and charcoal in relation to soil depth in five study sites

\begin{tabular}{lcccl}
\hline & & \multicolumn{2}{c}{${ }^{14} \mathrm{C}$ BP } & \\
\cline { 3 - 4 } Sites & Depth $(\mathrm{cm})$ & Humin & Charcoal & Difference $(\%)^{\mathrm{a}}$ \\
\hline Salitre $^{\mathrm{b}}$ & $0-10$ & $240 \pm 70$ & $160 \pm 75$ & Concordant \\
& $90-100$ & $3700 \pm 80$ & $3810 \pm 80$ & Concordant \\
& $150-160$ & $5550 \pm 80$ & $5930 \pm 100$ & 7 \\
Jaguariúna $^{\mathrm{c}}$ & $190-200$ & $6940 \pm 80$ & $8790 \pm 100$ & 27 \\
& $70-80$ & $4770 \pm 70$ & $4800 \pm 110$ & Concordant \\
& $110-120$ & $4840 \pm 220$ & $4550 \pm 70$ & Concordant \\
& $150-160$ & $5820 \pm 70$ & $6330 \pm 70$ & 9 \\
Anhembi & $200-210$ & $7490 \pm 350$ & $9120 \pm 90$ & 22 \\
& $40-50$ & $2500 \pm 60$ & $2520 \pm 60$ & Concordant \\
Botucatu I & $60-70$ & $2440 \pm 60$ & $2700 \pm 60$ & 11 \\
& $60-70$ & $3930 \pm 80$ & $3040 \pm 180$ & -23 (exception) \\
& $120-130$ & $5110 \pm 60$ & $5500 \pm 70$ & 8 \\
Botucatu II & $180-190$ & $6490 \pm 120$ & $6080 \pm 300$ & Concordant \\
& $50-60$ & $2490 \pm 100$ & $3080 \pm 70$ & 24 \\
& $90-100$ & $3880 \pm 50$ & $4630 \pm 80$ & 19 \\
& $120-130$ & $5010 \pm 50$ & $5660 \pm 270$ & 13 \\
& $180-190$ & $6460 \pm 70$ & $4150 \pm 450$ & -36 \\
\hline
\end{tabular}

${ }^{\text {a }}$ Relative to the humin

${ }^{b}$ Pessenda et al. 1996a

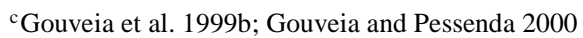

In general, the charcoal ages were similar and/or older than the humin ages, except for two sets of data that show younger ages for the charcoal (Table 3). The ages profiles obtained in the Salitre and Jaguariúna soils show the same pattern (Figure 3). Samples covering the first meter show similar ages for the charcoal and the humin. Then, below $150 \mathrm{~cm}$ the charcoal is up to $27 \%$ older than the humin. Another distinct pattern is observed in the Botucatu soil (II), that show older ages for the charcoal compared to the humin fraction excepting the deeper soil horizon that show significantly younger ages for the charcoal (Table 3). Since the sample was representative of a very small fragment (as can be observed by the high analytical error/uncertainty of \pm 450 ), this charcoal have probably been transported from shallow layers by the soil fauna. The other Botucatu age profile shows slightly younger age for the charcoal in the shallow soil horizon and similar ages for both dated materials in the deeper soil horizons. These results show the complexities of carbon cycling in soils and it implications for the evaluation of the most suitable material for ${ }^{14} \mathrm{C}$ dating of soil carbon. However, in the absence of charcoal the humin fraction is probably the best material for ${ }^{14} \mathrm{C}$ dating but these dates should be considered as minimum ages of the SOM. 


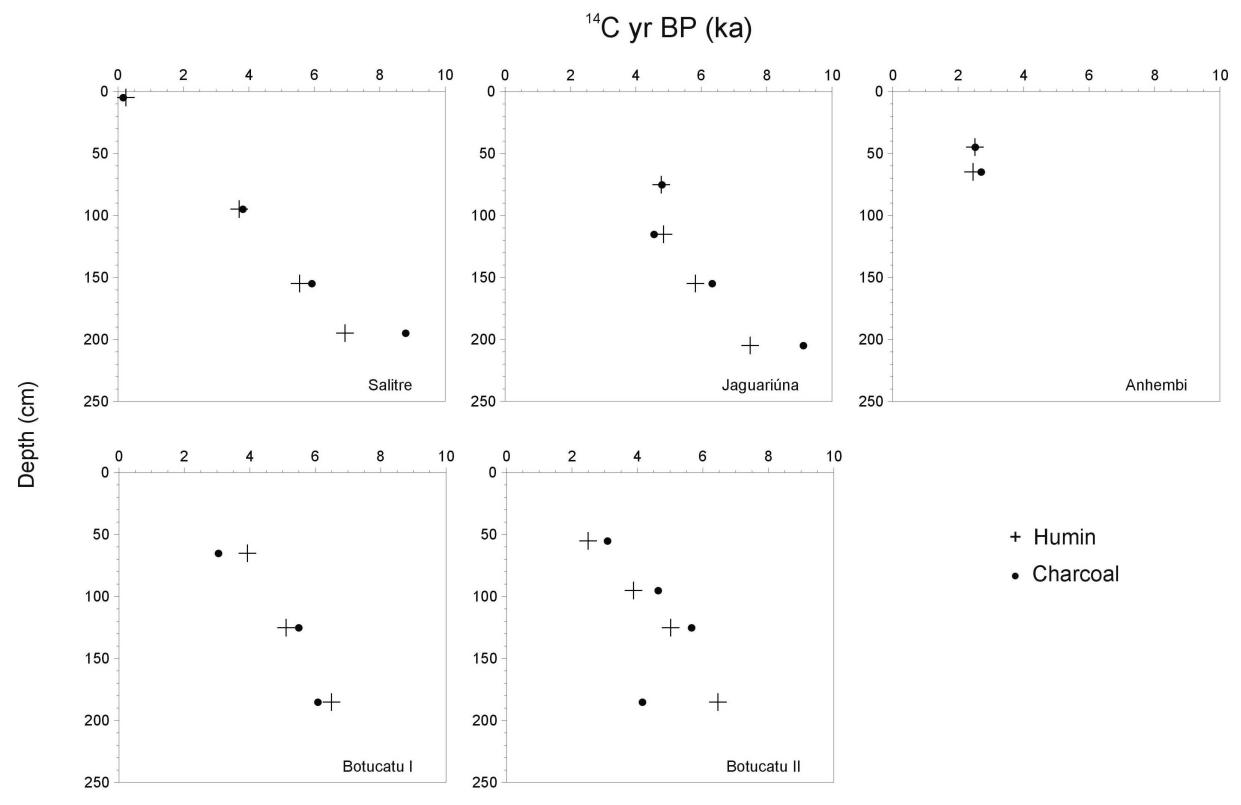

Figure 3 Comparison between the humin and charcoal ages

\section{CONCLUSIONS}

This study, performed in eight soils representative of a vast region of Brazil, clearly showed that SOM is not an appropriate material for ${ }^{14} \mathrm{C}$ dating. ${ }^{14} \mathrm{C}$ dates obtained on $\mathrm{SOM}$ are significantly younger than dates obtained in the humin fraction. This study also showed that the humin fraction is the more reliable material for ${ }^{14} \mathrm{C}$ dating in soil devoid of charcoal. In general, there was a good agreement of the ages between the humin fraction and buried charcoal in all the studied soils. Some soil horizons show the charcoal ages were around $20 \%$ older than the humin. A few exceptions show the opposite trend. Therefore, the ${ }^{14} \mathrm{C}$ dates obtained in the humin fraction should be considered as the minimum age of the SOM. It is recommended to date both the humin fraction and charcoal in soil studies dealing with the reconstruction of past vegetation in ecosystems composed of forest and savanna vegetation communities.

\section{ACKNOWLEDGMENTS}

We gratefully acknowledge financial support from São Paulo Foundation for Research (FAPESP), grant nr 95/3037-2, 95/5047-5, 96/1447-1, 96/12777-2, and from PRONEX grant nr 41.96.0938.00. We also thank MVL Cruz for ${ }^{14} \mathrm{C}$ analyses.

\section{REFERENCES}

Balesdent J. 1987. The turnover of soil organic fractions estimated by radiocarbon dating. The Science of the Total Environment 62:405-8.

Balesdent J, Guillet B. 1992. Les datations par le ${ }^{14} \mathrm{C}$ des matières organìques des sols. Contribution à l'étude de l'humification et du renouvellement des substances humiques. Science du Sol 2:93-112.

Becker-Heidmann P, Liang-WU L, Scharpenssel HW.
1988. Radiocarbon dating of organic matter fractions of a Chinese Mollisol. Z. Pflanzenernähr. Bodenk 151: 37-9.

Campbell CA, Paul EA, Rennie DA, McCallum KJ. 1967. Applicability of the carbon dating method of analysis to soil humus studies. Soil Science 104(3): 217-24.

European Science Foundation Handbooks for archaeolo- 
gists. First edition. Strasbourg: ESF, 1985. 65 p.

Goh KM, Rafter TA, Stout JD, Walker TW. 1976. The accumulation of soil organic matter and its carbon isotopes content in a chronosequence of soils developed on aeolian sand in New Zealand. Journal of Soil and Science 27:89-100.

Gouveia SEM, Pessenda LCR, Boulet R, Aravena R, Scheel-Ybert R. 1999a. Isótopos do carbono dos carvões e da matéria orgânica do solo em estudos de mudança de vegetação e clima no Quaternário e da taxa de formação de solos do estado de São Paulo. Anais da Academia Brasileira de Ciências 71(4-II): 969-80.

Gouveia SEM, Pessenda LCR, Aravena R. 1999b. Datação da fração humina da matéria orgânica do solo e sua comparação com idades ${ }^{14} \mathrm{C}$ de carvões fósseis. Química Nova 22(6):810-14.

Gouveia SEM, Pessenda LCR. 2000. Datation par $1 e^{14} \mathrm{C}$ de charbons inclus dans le sol pour l'étude du rôle de la remontée biologique de matière et du colluvionnement dans la formation de latosols de l'état de São Paulo, Brésil. Comptes Rendus de l'Académie des Sciences Paris, série IIa 330(2):133-8.

Martel YA, Paul EA. 1974. The use of radiocarbon dating or organic matter in the study of soil genesis. Soil Science of America Proceedings 38:501-6.

Nowaczyk B, Pazdur MF. 1990. Problems concerning the ${ }^{14} \mathrm{C}$ dating of fossil dune soils. Quaestiones Geographicae 11/12:135-51.

Pessenda LCR, Camargo PB. 1991. Datação radiocarbônica de amostras de interesse arqueológico e geológico por espectrometria de cintilação líquida de baixa radiação de fundo. Química Nova 14(2):98-103.

Pessenda LCR, Aravena R, Melfi AJ, Telles ECC, Boulet
R, Valencia EPE, Tomazello M. 1996a. The use of carbon isotopes $\left({ }^{13} \mathrm{C},{ }^{14} \mathrm{C}\right)$ in soil to evaluate vegetation changes during the Holocene in Central Brazil. Radiocarbon 38(2):191-201.

Pessenda LCR, Valencia EPE, Camargo PB, Telles ECC, Martinelli CA, Cerri CC, Aravena R, Rozanski K. 1996b. Natural radiocarbon measurements in Brazilian soils developed on basic rocks. Radiocarbon 38(2):203-8.

Pessenda LCR, Gouveia SEM, Aravena R, Gomes BM, Boulet R, Ribeiro AS. 1998. Radiocarbon dating and stable carbon isotopes of soil organic matter in forestsavanna boundary areas in the southern Brazilian Amazon forest. Radiocarbon 40(2):1013-22.

Pessenda LCR, Gouveia SEM, Aravena R. 2000. Dating of the total soil organic matter and humin fraction and its comparison with ${ }^{14} \mathrm{C}$ ages of fossil charcoal. In: 17th International Radiocarbon Conference. Program and Abstracts. Jerusalem.

Saldarriaga JG, West DC. 1986. Holocene fires in northern Amazon Basin. Quaternary Research 26:358-66.

Soubiès F. 1980. Existence d'une phase sèche en Amazonie brésilienne datée par la présence de charbons dans les sols (6000-3000 ans B.P.). Cahiers ORSTOM. Géologie 11(1):133-48.

Scharpenseel HW, Ronzani C, Pietig F. 1968. Comparative age determinations on different humic-matter fractions. In: Proceedings, Symposium on the Use of Isotopes and Radiation in Soil Organic Matter Studies, July 1968. Vienna: IAEA. p 67-74.

Trumbore SE. 1996. Applications of accelerator mass spectrometry to soil science. In: Boutton TW, Yamasaki SI, editors. Mass spectrometry of soils. New York: Marcel Dekker. p 311-40. 